\title{
Determinan Pemberian Air Susu Ibu (ASI) Ekslusif oleh Ibu Pekerja
}

\author{
Sri Purwanti \\ Universitas Islam Negeri (UIN) Syarif Hidayatullah Jakarta \\ E-mail : purwantimatriks77@gmail.com
}

\begin{abstract}
Abstrak: ASI ekslusif sangat bermanfaat untuk kesehatan ibu, dan bayi. Namun sekarang, di Indonesia terjadi peningkatan jumlah ibu yang tidak memberikan ASI eksklusif. Berdasarkan data dari Badan Pusat Statistik (BPS) rata rata anak berusia 2 sampai 4 tahun yang mendapat ASI hanya sebesar 19,87\%. Ada beberapa ibu yang tidak menyusui anaknya dikarenakan beberapa alasan misalnya karena harus segera bekerja. Untuk mengetahui determinan pemberian ASI eksklusif oleh ibu pekerja, maka dilakukan telaah terhadap naskah ataupun artikel ilmiah yang berkaitan dengan hal tersebut. Ada beberapa hal yang menjadi determinan pemberian ASI eksklusif diantaranya, perubahan sosial budaya, faktor psikologis, umur, sikap, dukungan pengasuh, ketersediaan fasilitas, dukungan lingkungan sekitar dan keluarga terdekat seperti suami serta perusahaan yang mempekerjakannya. Diperlukan adanya kontribusi penuh baik dari lingkungan keluarga, perusahaan, maupun pemerintah selaku penentu kebijakan untuk turut serta mengupayakan pemberian ASI eksklusif.
\end{abstract}

Kata kunci : ASI Eksklusif, determinan, ibu pekerja

\section{PENDAHULUAN}

Pemberian ASI merupakan upaya yang bermanfaat baik untuk kesehatan ibu maupun bayi. Hal ini dikarenakan ASI mengandung zat gizi yang sangat dibutuhkan saat pertumbuhan serta beberapa zat lain yang esensial untuk tubuh seperti kolostrum

Kolostrum mengandung zat antibodi yang baik untuk kesehatan, kekebalan tubuh, dan gizi bayi. Kolostrum merupakan air susu ibu yang keluar pada hari hari pertama setelah kelahiran. Kolostrum berwarna bening atau putih kekuning kuningan. Pemberian kolostrum merupakan salah satu upaya untuk meningkatkan kekebalan bayi baru lahir dan sekaligus mematangkan usus bayi. Oleh karena itu pemberian ASI utamanya pada awal fase kelahiran atau disebut dengan Inisisi menyusu dini merupakan hal yang sangat dianjurkan.
Inisiasi menyusu dini yang diupayakan oleh ibu mempunyai peran penting dalam merangsang kontraksi uterus sehingga megurangi perdarahan pasca melahirkan (postpartum) sedangkan Menyusui jangka panjang dapat memperpanjang jarak kelahiran karena masa amenorhoe lebih panjang, sehingga masa pemulihan status gizi ibu akan menjadi lebih baik sebelum kehamilan berikutnya. Berdasarkan alasan tersebut maka WHO dan UNICEF merekomendasikan upaya pemberian ASI Eksklusif selama enam bulan (Riskesdas, 2010). Menyusui eksklusif berarti tidak memberi makanan atau minuman lain, termasuk air putih kecuali obat obatan dan vitamin atau mineral tetes kepada bayi.

Pemberian ASI Ekslusif berlangsung selama Enam Bulan. Setelah enam bulan. Jadi, seorang bayi baru dapat diberikan makanan pendamping ASI sampai bayi berumur minimal 2 tahun. Mengenai pemberian ASI Ekslusif juga 
sudah direkomendasikan oleh pemerintah indonesia (Riskesdas, 2013). Namun belum muncul adanya pemahaman penuh dan perilaku positif terkait hal ini, baik di dunia, dan di Indonesia khususnya.

Penggunaan air susu ibu di beberapa negara sudah mengalami penurunan. Di Amerika, pada permulaan abad 20, kira kira $71 \%$ bayi mendapat ASI sampai umur kurang lebih 6 bulan, sedangkan pada tahun 1971, angka ini menurun menjadi 25\% pada ibu ibu dengan sosial ekonomi sedang dan 5\% pada ibu dengan sosial ekonomi baik. Di Singapura, pada tahun 1951, pada ibu dengan sosio ekonomi sedang dan baik $48 \%$ bayi mendapat air susu ibu sedangkan pada golongan sosio ekonomi rendah $71 \%$. Pada tahun 1961, angka tersebut merosot menjadi masing masing $8 \%$ dan $42 \%$ (Soetjiningsih, 1997).

Data lain terkait pemberian ASI Ekslusif menyatakan bahwa bayi yang berumur 0 bulan dan diberi air susu secara ekslusif hanya sebesar $39,8 \%$. Persentase menyusui ekslusif semakin menurun dengan meningkatnya kelompok umur bayi. Pada bayi yang berumur 5 bulan persentasenya hanya $15,3 \%$. Selain itu menyusui ekslusif lebih tinggi pada bayi laki laki dibanding perempuan, dan lebih tinggi di pedesaan daripada di perkotaan (Riskesdas, 2010).

Ada pola yang khas dalam pemberian ASI ekslusif berdasarkan pendidikan kepala keluarga dan status ekonomi. Pendidikan kepala keluarga dan status ekonomi berbanding terbalik dengan persentase menyusui ekslusif. Artinya semakin tinggi status ekonomi dan tingkat pendidikan semakin rendah presentase menyusui ekslusif (Riskesdas, 2010).

Di Indonesia, terjadi peningkatan jumlah ibu yang tidak menyusui bayinya. Berdasarkan data dari Badan Pusat Statistik (BPS) rata rata anak berusia 2 sampai 4 tahun yang mendapat ASI ekslusif sebesar 20,00 \% pada tahun 2009, jumlah yang sama terjadi pada tahun 2010. Namun, pada tahun 2011 mengalami penurunan menjadi 19, 68\%, kemudian 19,41\% pada tahun 2012 dan mengalami kenaikan pada tahun 2013 menjadi 19,87\% (BPS, 2015).

Sementara rata- rata anak berusia 2-4 tahun yang disusui dengan makanan tambahan adalah $16.00 \%$ pada tahun $2009,15,00 \%$ pada tahun 2010, 14,98\% pada 2011, dan $14,6 \%$ pada tahun 2012, bahkan mengalami peningkatan pada tahun 2013 menjadi 15,01\%.

Rata-rata anak berusia 2- 4 tahun yang disusui tanpa makanan tambahan sebesar 4,00\% pada tahun 2009, pada tahun 2010 sebesar 5,00\%, pada tahun 2011 sebesar 4,7\%, dan $4,81 \%$ pada tahun 2012 , kemudian mengalami peningkatan pada tahun 2013 menjadi 4, 86\% (BPS,2015).

Informasi terkait PMBA (Pemberian Makanan Bayi dan Anak) merupakan hal penting. Sebagaimana disebutkan oleh UNICEF dalam Global Strategy on Infant and Young Child Feeding (IYCF) tahun 2002 disebutkan bahwa 54\% kematian bayi dan anak terkait dengan gizi kurang. Gizi kurang tersebut terkait dengan pemberian makanan bayi dan anak yang kurang tepat. Pola pemberian ASI yang optimal antara lain, Inisiasi Menyusu Dini (IMD) dalam 30 sampai 60 menit setelah bayi lahir, memberikan ASI secara eksklusif kepada bayi sejak lahir sampai usia 6 bulan, dan mulai memberikan Makanan Pendamping ASI (MPASI) sejak bayi berusia 6 bulan, dan meneruskan pemberian ASI sampai anak berusia 2 tahun atau lebih (Depkes, 2015).

Ada beberapa ibu yang tidak menyusui anaknya dikarenakan beberapa alasan. Misalnya, tidak mau, susah menyusui, tidak mau susah menyapih karena harus segera bekerja, dll (budiasih, 2008).

Pemberian ASI Ekslusif bagi bayi merupakan hal penting untuk meningkatkan kesehatan anak Indonesia sekaligus sebagai langkah awal pembentukan generasi cerdas untuk membentuk Sumber Daya Manusia Indonesia yang berkualitas, dan berkompeten. Namun ada 
beberapa faktor yang berperan sebagai determinan (faktor penentu) pemberian ASI Ekslusif oleh ibu pekerja yang turut mempengaruhi seseorang ibu untuk memberikan ASI ekslusif pada bayinya.

Oleh karena itu disusunlah Karya tulis ini dengan judul "Determinan Pemberian Air Susu Ibu (ASI) Ekslusif oleh Ibu Pekerja”

\section{METODE PENELITIAN}

Metode yang digunakan dalam penelitian karya tulis ini adalah telaah terhadap berbagai sumber referensi baik berupa buku, naskah, jurnal, ataupun artikel ilmiah, serta data data dari instansi atau lembaga terkait. Adapun sumber referensi yang dijadikan sebagai rujukan diakses melalui Google Scholar.

Sumber referensi yang diambil adalah yang bersesuaian dengan judul karya tulis yaitu "Determinan Pemberian Air Susu Ibu (Asi) Ekslusif Pada Ibu Pekerja”. Dari beberapa artikel/jurnal yang dijadikan sebagai sumber referensi memiliki berbagai desain penelitian. Berbagai sumber informasi tersebut dikumpulkan, dianalisis secara mendalam untuk kemudian disajikan dalam satu bentuk susunan karya ilmiah.

\section{HASIL DAN PEMBAHASAN}

Air Susu Ibu (ASI) merupakan makanan pertama bayi Selama beberapa bulan pertama dan sekaligus berperan sebagai zat gizi terbaik untuk memenuhi kebutuhan bayi. $\mathrm{Hal}$ ini dikarenakan ASI memiliki beberapa kandungan zat gizi misalnya protein, laktase dan garam garam organik yang disekresi oleh kedua kelenjar payudara ibu. Komposisi ASI ternyata tidak sama dari waktu ke waktu. Faktor faktor yang mempengaruhi antara lain, stadium laktasi, ras, kedaan nutrisi, diet ibu dll (Dinkes, 2013).

ASI eksklusif adalah pemberian ASI (air susu ibu) sedini mungkin setelah persalinan, diberikan tanpa jadwal dan tidak diberi makanan lain, walaupun hanya air putih, sampai bayi berumur 6 bulan. Setelah 6 bulan, bayi mulai dikenalkan dengan makanan lain dan tetap diberi ASI sampai bayi berumur dua tahun (Dinkes, 2013).

Berbagai kajian dalam 2 dekade terakhir menyatakan bahwa ASI merupakan sumber nutrisi terbaik bagi bayi karena mengandung berbagai zat gizi esensial.dianjurkan bagi ibu untuk menyusui bayinya secara ekslusif selama 6 bulan pertama kehidupan dan pemberian ASI dilanjutkan dengan didampingi makanan pendamping ASI, idealnya selama 2 tahun pertama kehidupan. Pada jam - jam pertama setelah melahirkan dikeluarkan hormon oksitosin yang bertanggung jawab terhadap produksi ASI. Bayi baru lahir sehat diberikan langsung kepada ibunya untuk mendapatkan kontak kulit dengan ibunya. Kontak kulit ke kulit awal yang baik dapat meningkatkan lama menyusui (IDAI, 2015).

Telah diketahui bahwa menyusui memiliki banyak manfaat bagi ibu maupun bayinya. Antara lain sebagai berikut

Pertama, Perlindungan kesehatan bayi. Menyusu eksklusif selama 6 bulan terbukti memberikan risiko yang lebih kecil terhadap berbagai penyakit infeksi seperti diare, infeksi saluran napas, infeksi telinga, pneumonia, infeksi saluran kemih dan penyakit lainnya seperti obesitas, diabetes, alergi, penyakit inflamasi saluran cerna, kanker pada kemudian hari. Bayi yang mendapat ASI lebih sedikit memerlukan rawat inap dibanding bayi yang mendapat susu formula. Zat kekebalan yang berasal dari ibu dan terdapat dalam ASI akan ditransfer ke bayi untuk membantu mengatur respons imun tubuh melawan infeksi (IDAI, 2015).

Kedua, meningkatkan kesehatan saluran cerna Keuntungan lain menyusui adalah ASI lebih mudah dicerna dibandingkan susu formula (IDAI, 2015). 
Ketiga, menambah Intelegensi bayi. Berdasarkan kajian ilmiah, menyusu dapat berpengaruh terhadap perkembangan intelektual anak, karena menyusui memberikan pelekatan erat dan rasa nyaman yang berpengaruh terhadap perkembangan emosi anak. Anak yang disusui mempunyai intelegensia dan emosi lebih matang yang sangat berpengaruh terhadap kehidupan sosialnya di masyarakat (IDAI, 2015).

Beberapa publikasi penelitian tentang efek menyusui terhadap IQ bayi memperlihatkan bahwa bayi yang mendapat ASI mempunyai nilai IQ 3-5 lebih tinggi dibandingkan bayi yang mendapat susu formula. Makin lama bayi menyusu, makin besar efek positif pada IQ bayi. Tingkat IQ lebih tinggi dikaitkan dengan kandungan nutrisi yang ditemukan pada ASI (IDAI, 2015).

Keempat, rasa nyaman dan hangat selama menyusui. Para ahli di bidang psikologi meyakini bahwa bayi dapat menikmati rasa aman, kehangatan, dan keberadaan ibunya, khususnya bila terjadi 'kontak kulit-ke-kulit' selama menyusu. Perasaan tersebut mungkin kurang diperoleh oleh bayi yang mendapat susu botol. Oleh karena itu 'kontak kulit-ke-kulit' menjadi bagian penting dalam perawatan bayi sehari-hari. Ibu harus sesering mungkin memberikan sentuhan kasih sayang kepada bayinya, karena hal tersebut merupakan sumber kehangatan dan kenyamanan(IDAI, 2015) .

Menurut UU No. 13/2003 pasal 83 tentang Ketenagakerjaan menyatakan bahwa perempuan yang anaknya masih menyusui harus diberi kesempatan sepatutnya untuk menyusui anaknya jika hal itu harus dilakukan selama waktu kerja.

Manfaat ASI yang sudah diketahui tersebut ternyata belum mampu membangkitkan kesadaran ibu untuk menyusui anaknya di 6 bulan pertama dari hari kelahiran.Pemberian ASI mulai menurun. Di kota - kota besar, terlihat adanya tendensi penurunan pemberian air susu ibu, yang dikhawatirkan akan terjadi di negara negara maju dan meluas ke pedesaan. Penurunan pemberian atau penggunaan air susu ibu di negara negara berkembang atau di pedesaan terjadi karena adanya kecenderungan dari masyarakat untuk meniru sesuatu yang dianggapnya modern yang datang dari kota besar (Soetjiningsih, 1997).

Adapun faktor faktor yang mempengaruhi hal tersebut antara lain perubahan sosial budaya. Yang meliputi kesibukan sosial, seperti bekerja, meniru teman, tetanggga atau orang terkemuka yang memberikan susu botol, merasa ketinggalan jika menyusui bayinya. Selain itu faktor psikologis juga berperan misalnya, takut kehilangan daya tarik sebagai seorang wanita, ataupun tekanan batin (Soetjiningsih, 1997).

Faktor fisik ibu juga menjadi salah satu faktor yang mempengaruhi pemberian ASI Ekslusif oleh ibu pekerja, misalnya keadaan ibu yang sering sakit atau lainnya (Soetjiningsih, 1997).

Sementara dalam pelayanan kesehatan, salah satunya dikarenakan faktor kurangnya petugas kesehatan, sehingga masyarakat kurang mendapat penerangan atau dorongan terkait manfaat pemberian ASI. Hal itu diiringi dengan meningkatnya promosi susu kaleng sebagai pengganti ASI dan justru ditambah dengan keterangan yang salah dari petugas kesehatan sendiri yang menganjurkan penggantian ASI dengan susu kaleng (Soetjiningsih, 1997).

Pada penelitian yang dilakukan oleh Inayah terkait determinan perilaku pemberian air susu ibu eksklusif pada pekerja diketahui bahwa pemberian asi eksklusif dihentikan dengan alasan jumlah ASI mereka tidak dapat memenuhi kebutuhan bayi. Hanya sebagian kecil $(1,7 \%)$ responden menyatakan sibuk sehingga berhenti menyusui. Namun, penelitian ini belum menggali informasi secara mendalam mengenai faktor psikologis dan fisiologis sebagai penyebab utama jumlah ASI sedikit (Inayah, 2013).

Berdasarkan penelitian yang dilakukan oleh gibney dalam (Saleh, 2011). Menyatakan 


\section{8-20 | HARKAT: Media Komunikasi Islam Tentang Gender dan Anak, 11 (1), 2015}

bahwa banyak sikap dan kepercayaan yang tidak mendasar terhadap makna pemberian ASI eksklusif selama 6 bulan. Umumnya alasan ibu tidak memberikan ASI eksklusif meliputi rasa takut yang tidak berdasar bahwa ASI yang dihasilkan tidak cukup atau tidak memiliki mutu yang baik, keterlambatan memulai pemberian ASI dan pembuangan kolostrum, teknik pemberian ASI yang salah, serta kepercayaan yang keliru bahwa bayi haus dan memerlukan cairan tambahan (Sholeh, 2011)

Pada analisis multiariat dalam penelitian yang sama ditemukan bahwa variabel umur, sikap, dukungan pengasuh, dan ketersediaan fasilitas berhubungan dengan perilaku pemberian ASI eksklusif. Variabel sikap merupakan variabel yang paling dominan berhubungan dengan perilaku ibu (Inayah, 2013).

Rasa percaya diri untuk memberi ASI eksklusif merupakan modal penting dalam keberhasilan proses menyusui. Semakin positif sikap ibu, semakin besar peluang ibu dapat memberikan ASIeksklusif. Sikap kurang mendukung tersebut salah satunya dikarenakan dibatasi oleh jam kerja. Penelitian tersebut juga mengemukakan bahwa sikap ibu yang tidak mendukung jika pemerintah dan pengusaha menambahkan waktu cuti melahirkan bagi ibu pekerja lebih dari 3 bulan (Inayah, 2013).

Sejauh ini pemerintah maupun Lembaga Sosial Masyarakat (LSM) telah mensosialisasikan ASI eksklusif. Sosialisasi ini dilakukan baik secara langsung melalui tenaga kesehatan seminar seminar atau tidak langsung melalui media masa seperti buku dan internet (Inayah, 2013).

Hubungan yang bermakna juga ditemukan antara ketersediaan fasilisitas dengan pemberian ASI eksklusif. Semakin tersedia fasilisitas di kantor dan ketersediaan fasilisitas yang dimiliki atau dibawa ibu selama proses menyusui secara eksklusif. Namun, dalam uji statistik menunjukan tidak tidak terdapat hubungan bermakna antara ketersediaan fasilisitas di kantor dengan pemberian ASI eksklusif. Berdasarkan penelitian ini, keberadaan pojok ASI ternyata tidak berhubungan dengan pemberian ASI eksklusif pada ibu pekerja. Meskipun kantor menyediakan pojok ASI pekerja lebih memilih memerah ASI saat di rumah. Ketika di kantor, ibu tidak selalu memerah ASInya di pojik ASI, tapi dapat melakukannya di klinik kantor, di ruang kerja, dan di musholla. Tapi keberadaan ruang laktasi diperlukan untuk penitipan anak bagi ibu pekerja yang membawa anak sekaligus sebagai tempat berbagi dan bertukar informasi dan pengalaman sebagai salah satu bentuk dukungan dalam menyusui (Inayah, 2013).

Ketersediaan fasilitas seperti plastik penyimpanan ASI dan alat pendingin memiliki hubungan dengan pemberian ASI eksklusif. Ibu yang lama meninggalkan bayi dapat menjadi faktor penyebab gagalnya pemberian ASI eksklusif (Inayah, 2013).

Dukungan suami juga berpengaruh. Ibu yang mendapat dukungan suami cenderung memberikan ASI eksklusif dua kali lebih besar daripada ibu yang kurang mendapat dukungan dari suami.

Stress akaibat pekerjaan juga merupakan hambatan dalam menyusui eksklusif dan mengganggu kesinambungan. Pimpinan yang tetap menuntut ibu menyusui untuk bekerja sesuai jam kerja dengan beban kerja yang sama berat seperti karyawan biasa dapat menjadi kendala besar untuk mencapai keberhasilan pemberian ASI eksklusif. Namun, dalam penelitian ini tidak menemukan hubungan yang bermakna antara dukungan pimpinan dengan pemberian ASI eksklusif (Inayah, 2013).

Terkait dengan dukungan program ASI eksklusif di tempat kerja telah diatur dalam PP No. 33 tahun 2012 pasal 30 tentang pemberian ASI eksklusif. Dukungan ini dilaksanakan sesuai dengan peraturan perusahaan antara pengusaha dan pekerja/buruh atau melalui perjanjian kerjasama antara serikat pekerja/serikat buruh dengan pengusaha. Sebagai bentuk dukungan institusi terhadap program menyusui eksklusif, 
kementrian kesehatan sudah menyediakan ruang laktasi. Namun, pimpinan masih meminta ibu menyusui eksklusif dan tetap bekerja sesuai jam kerja (Inayah, 2013).

Sebagian besar pimpinan tidak memperhatikan manfaat pemberian ASI eksklusif saat bekerja. Masih sangat sedikit perusahaan yang membuat aturan tentang menyusui di tempat kerja bagi ibu pekerja. Bridge (1997) dalam (Setyawati, 2011) mengungkapkan bahwa sebagian besar pimpinan perusahaan tidak perhatian terhadap pekerja wanita yangingin menyusui bayinya di tempat kerja. Sedikitnya perhatian pimpinan ini menyebabkan beberapa ibu pekerja merasa malu dan harus bersembunyi bila ingin menyusui bayinya atau hanya sekedar memompa ASI.

Dukungan orang sekitar seperti pengassuh, orang tua/mertua dan pembantu rumah tangga berhubungan dengan pemberian ASI eksklusif. ibu yang mendapat dukungan dari orang sekitranya memiliki peluang yang lebih besar untuk menyusui anknya secara eksklusif (Inayah, 2013).

Dukungan petugas kesehatan terkait dengan pemberan ASI eksklusif tidak berhubungan dengan pemberian ASI eksklusif. Diketahui bahwa belum semua petugaskesehatan memberi dukungan dalam pemberian ASI eksklusif

\section{PENUTUP}

Ada beberapa hal yang menjadi determinan pemberian ASI eksklusif diantaranya, perubahan sosial budaya, faktor psikologis, umur, sikap, dukungan pengasuh, ketersediaan fasilitas, dukungan lingkungan sekitas misalnya suami serta perusahaan yang mempekerjakannya.Oleh karena itu diperlukan adanya dukungan penuh baik dari lingkungan keluarga, perusahaan, maupun pemerintah selaku penentu kebijakan untuk turut serta mengupayakan pemberian ASI eksklusif.
Untuk lingkungan keluarga sebaiknya melakukan dorongan dan motivasi penuh untuk meyakinkan ibu bahwasanya dia mampu menyusui anaknya secara eksklusif. Peran ini bisa dilaksanakan oleh suami, ibu, ataupun nenek dari ibu yang menyusui. Adapun bagi perusahaan sebaiknya juga memberikan dorongan serta motivasi kepada pekerjanya sekaligus menyediakan fasilitas penunjang untuk pemberian ASI eksklusif seperti keringanan waktu untuk menyusui atau memompa air susu di sela sela jam bekerja atau penyediaan ruang laktasi secara khusus.

Untuk pemerintah yang memiliki wewenang dari peraturan ynag dibuat sebaiknya lebih memberikan perhatian untuk masalah ini. Terlebih untuk mengontol perusahaan yang terbukti membertakan pekerja wanita terkait pemberian ASI eksklusif.

\section{DAFTAR PUSTAKA}

Abdullah, Inayah dan Ayubi, Diyah, 2013. Determinan Perilaku Pemberian Asi Susu Ibu Eksklusif pada Ibu Pekerja.diakses dari http://jurnalkesmas.ui.ac.idindex./phpkes masarticleviewFile2728 Pada 5 September 2015

Amal Sholeh, La Ode, 2011. Faktor Faktor yang Menghambat Praktik ASI Eksklusif pada Bayi Usia 0-6 Bulan. Diakses dari http://core.ac.ukdownloadpdf1 1734484.p df pada 7 September 2015

BPS (Badan Pusat Statistik), 2015.data sensus, diakses dari http://www.bps.go.id/linkTabelStatis/view /id/1559 pada 1 September 2015

Budiasih, Kun Sri, 2008. Hand Book Ibu Menyusui. Bandung : PT. Karya Kita.

Depkes, 2010.Riset Kesehatan Dasar.diakses dari http://www.litbang.depkes.go.id/sites/dow nload/buku_laporan/lapnas_riskesdas 2010 /Laporan_riskesdas_2010.pdf Pada 5 September 2015 
Depkes, 2013. Riset Kesehatan Dasar.diakses dari

http://www.depkes.go.id/resources/downlo $\mathrm{ad} /$ general/Hasil\%20Riskesdas\%202013.p df.Diakses pada 5 September 2015

Depkes, 2015. Workshop Sinkronisasi Kuesioner Terkait PMBA dalam SDKI, Susenas, dan Riskesdas. Diakses dari http://gizi.depkes.go.id/workshopsinkronisasi-kuesioner-terkait-pmbadalam-sdki-susenas-danriskesdas?s=ASI+EKSKLUSIF pada 1 September 2015

Dinkes, 2013. Pentingnya ASI Ekslusif. Diakses dari

http://dinkes.pamekasankab.go.id/index.p hp/berita/174-pentingnya-asi-ekslusif pada 3September 2015
IDAI,2015.Nilai Menyusui. Diakses dari http://idai.or.id/publicarticles/klinik/asi/nilai-menyusui.html pada 3 September 2015

Setyawati, 2011.Pentingnya Motivasi dan Persepsi Pimpinan Terhadap Perilaku Pemberian ASI eksklusif pada Ibu Pekerja. Diakses dari http://download.portalgaruda.orgarticle.ph particle $=3692 \&$ val $=308 \mathrm{htt}$ download .port algaruda.orgarticle.phparticle $=3692 \&$ val $=3$ 08 pada 7 September 2015

Soetjiningsih, 1997.ASI Petunjuk untuk Tenaga Kesehatan.Jakarta: EGC 